\title{
Why Does an Auditor Not Issue a Going Concern Opinion for a Failing Company? Impact of Financial Risk, Time to Bankruptcy, and Cognitive Style
}

\author{
Erkki K. Laitinen, Teija Laitinen \\ ACA Research Group, Faculty of Business Studies, University of Vaasa, Vaasa, Finland \\ Email: ekla@uva.fi, tla@uva.fi
}

How to cite this paper: Laitinen, E.K. and Laitinen, T. (2020) Why Does an Auditor Not Issue a Going Concern Opinion for a Failing Company? Impact of Financial Risk, Time to Bankruptcy, and Cognitive Style. Theoretical Economics Letters, 10, 131-153.

https://doi.org/10.4236/tel.2020.101009

Received: January 10, 2020

Accepted: February 15, 2020

Published: February 18, 2020

Copyright $\odot 2020$ by author(s) and Scientific Research Publishing Inc. This work is licensed under the Creative Commons Attribution International License (CC BY 4.0).

http://creativecommons.org/licenses/by/4.0/

\begin{abstract}
This study investigates the effects of client's financial risk, time to bankruptcy, and auditor's cognitive style on issuing a Going Concern Opinion (GCO) for failing companies. Empirical tests are based on financial data from 328 bankrupt firms and peer review data from 172 auditors. Cognitive style on an intuitive-analytic dimension is approximated by the degree of auditor's compliance with the ISA standards for analytic procedures in peer review. Empirical findings support research hypotheses and show that seriousness of the financial risk and time distance to bankruptcy are important determinants of GC judgment accuracy. They also show that the performance of the cognitive style of the auditor is related to the fit between the cognitive style and the characteristics of the GC situation. The results indicate that an auditor's individual characteristics, i.e. cognitive style, affect his/her decision making when issuing GCO. This study is the first approach that systematically investigates the relationship between financial risk, distance to bankruptcy, and cognitive style on GC judgment in an archival research.
\end{abstract}

\section{Keywords}

Going Concern Opinion, Failing Firms, Financial Risk, Time to Bankruptcy, Cognitive Style, Finnish Small Firms

\section{Introduction}

The GCO on the financial statements of a firm is an important issue that attracts a lot of public attention. When considering the opinion, the auditor is faced by a difficult task. If the auditor gives a modified opinion, the financial situation of 
the firm can further deteriorate either leading to self-fulfilling prophecy (bankruptcy) or to a serious damage in the customer relationship and future client profitability. If the auditor, however, does not issue a GCO on the financial statements of a bankrupt firm, it leads to obvious increase of litigation risk. Therefore, GCO has been an object for keen academic research for the last decades [1] [2] [3]. Previous studies have shown that auditors focus on client characteristics and distress rather than auditor economic incentives or litigation risk when evaluating clients as a Going concern [4]. These studies generally suggest a set of specific client characteristics including violation of debt covenants, low Z-scores, disclosed plans to alleviate financial distress, life-cycle stage, size, and corporate governance factors. However, smaller body of previous research has paid attention to the auditor cognitive process preceding a GCO [2]. In this process auditor's experience and knowledge (individual characteristics) can play an important role [5] [6].

Although there are plenty of studies on GCO, empirical evidence is fragmented and contradictory. Bonner [7] examined the relationship between auditor cognitive processes and GC judgment and concluded that differences in complexity across GC decision-making tasks likely account for some of the differences in the results of studies. In experimental research, task complexity is related to the number of processing steps, the number of information cues available, the number of decision alternatives, and the correlation between information cues [8]. The main argument of this study is that in archival research the GC task complexity is related to the following two dimensions: estimated financial risk of the client and the time distance between the annual closing of accounts and the bankruptcy date. When the estimated financial risk of the client is not high and the time distance to bankruptcy is long, to assess GC correctly is a very difficult and complicated task. However, when the estimated risk is high and the time distance to bankruptcy is short, the main cues are negative and correlate with each other so that the number of relevant cues is reduced. In this simple situation, the number of decision alternatives is limited and the number of processing steps can be low. When the estimated financial risk is lower and the time distance to bankruptcy longer, the complexity of the task will increase.

The performance of the auditors in issuing a GCO largely depends also on the cognitive style of the auditor [9]. However, in order to result in a high performance in GCO there must be a fit between the characteristics of the task and the cognitive style of the author. Otherwise, there is a cognitive misfit, which impairs the performance [9] [10]. The situation where the structured financial information is dominant, analytic auditors may reach the best results in issuing a GCO to a bankruptcy firm. However, if there is a lot of unstructured non-financial information, it can be expected that intuitive auditors perform better than analytic auditors do. In situation where auditors have only little structured financial information and little unstructured non-financial information, it is probable that both analytic and intuitive auditors perform equally well. In these situations, there can be other auditor characteristics, which explain the differences in the 
accuracy of GC judgments.

Therefore, the hypotheses of the study are associated with the complexity of the GC judgment situation (task) and its fit with the cognitive style of the auditor. It is proposed that the characteristics of the client situation before bankruptcy and the individual characteristics of the auditor in correct and incorrect classifications of bankrupt firms differ with respect to complexity. Thus, the objective of the study is to assess two sets of hypotheses on:

1) The effect of the client situation and

2) The cognitive style of the auditor on GC judgment accuracy using a sample of Finnish bankrupt firms.

In this study, it will be shown that empirical evidence supports these hypotheses, which implies that contradictory results in previous archival studies can at least partly be resulted from the differences in the complexity of bankrupt situation and the cognitive straits of the auditors in the sample. It also implies that when assessing GC auditors should be very careful especially in cases where the estimated financial risk of the client is not high and the threat of bankruptcy is not immediate. In these cases, the rate of misclassification is very high so that only a minority of bankrupt clients usually has got a GCO.

This study is the first approach that systematically investigates the relationship between financial risk, distance to bankruptcy, and cognitive style on GC judgment in an archival research. It contributes to the research on auditing and failure prediction when showing that an auditor's accuracy in issuing a GCO largely depends on three factors: estimated financial risk of the client, time to bankruptcy, and her or his cognitive style in decision-making. The content of this study is as follows. In this introductory section, the background and the objective of the study are presented. In the second section, the hypotheses are derived from prior research while the third section presents the empirical data and methods. The fourth section presents the empirical findings and the last section summarizes the study.

\section{Prior Studies and Hypotheses}

The GC evaluation made by an auditor is based on knowledge obtained from audit procedures, and knowledge of conditions and events existing at or prior to the completion of fieldwork, that is related to the validity of the GC assumption and the use of the GC basis for preparing the financial statements [3]. The auditor is also required to obtain information about managerial plans to mitigate any concerns and assess the likelihood of successful implementation of these plans. However, if the auditor still has substantial doubt about the ability of the client to continue as GC, he or she should consider the adequacy of disclosures in financial statements. Furthermore, the auditor must modify his or her opinion to include an explanatory paragraph outlining the reasons for concern. The factors that affect the GC evaluation can be classified as client factors, auditor factors, auditor-client relationship factors, and environmental factors. In this review, a 
limited set of client and auditor factors are considered to focus on the relevant area. Similarly, hypotheses are analytically drawn for a simplified GCO process of a failing (bankrupt) client.

\section{Client characteristics}

There are a variety of client characteristics associated with the issuance of GCO. Firstly, the most important client factor is financial statement information that includes financial ratios, such as profitability, leverage, and liquidity prior to GCO. Prior archival studies have generally found that auditors are more likely to issue a GCO when the client are less profitable [11] [12], have higher leverage [13] [14], have lower liquidity [11] [12], and are smaller [15]. In a survey research, LaSalle \& Anandarajan [16] showed that the top financial ratios used by auditors in practice are the following: 1) net worth/total liabilities, 2) cash flows from operations/total liabilities, 3) current assets/current liabilities, 4) total liabilities/total assets, and 5) change in net worth/total liabilities. However, auditors generally use also multivariate bankruptcy prediction models, such as Altman Z-score, to improve ability to identify a financially distressed client [17] [18] [19].

Secondly, non-financial client information that includes market variables, strategic initiatives, and governance characteristics is also important. When predicting GC reporting, Behn, Kaplan \& Krumwiede [20] analyzed voluntarily disclosed managerial plans to alleviate financial distress (increase ownership equity, borrow money, restructure debt, and reduce spending or dispose of assets). They showed that auditors are less likely to issue GCO when management disclosed plans to issue equity or to borrow additional funds. Riley, Behn \& Pany [21] found that management plans can provide GC resolution information to the market as to whether a client will likely resolve the GC problem. In addition, auditors can rely on their own intimate knowledge of the client, client industry, and client management characteristics when forecasting client distress and seceding whether to issue GCO [22]. However, Arnold, Collier, Leech \& Sutton [23] concluded that auditors should be cautious when considering such non-financial information, because more experienced specialists can be better able to identify distressed clients.

\section{Auditor characteristics}

Evidence shows that as an auditor's expertise in an industry grows, so does the ability to interpret the financial distress of a client embedded in that industry. More experienced auditors are able to make better GC judgments when being able to identify a typical audit event and to have a larger extent of knowledge abstractness [24]. Similarly, auditors with better industry expertise are more likely to issue a GCO [25]. In general, GC decisions can be influenced by experience [26] and by prior involvement and beliefs, even where the information is redundant [27]. The ability of an auditor to identify distressed clients on the basis of non-financial information is also related to experience [23]. However, evidence on the effect of audit fees (economic dependence of an auditor) and auditor size 
on the propensity to issue a GCO is mixed [3]. Evidence however shows that auditors in unlimited liability partnerships are more likely to issue modified audit opinions than are auditors in limited liability corporations (organizational form effect), maybe due to lower auditor reporting conservatism [28].

There are two important effects in GC decision making that have an impact on the cognitive process of an auditor. Firstly, the order in which auditors receive evidence may influence GC judgments thus leading to a recency effect bias [29] [30] [31]. Due to this bias the auditor considers more recent information more important although there are not found any differences in importance. However, a simple decision aid to prompt auditors to consider the chronological order of evidence can eliminate recency effects in GC judgments [31]. Secondly, there is a bias to consider negative evidence more important than positive evidence. Thus, auditors attend more to negative information about the client than to positive information in GC settings [16]. This bias may be related to that auditors are potentially risk-averse when deciding whether to issue a GCO because of potential litigation concerns involved with issuing a clean opinion for clients that fail [2].

\section{Hypotheses on failing firms}

Previous studies indicate that the founding basis of GC judgment is got from the financial statement analysis of the client often based on a use of a prediction model. Typically, this prediction model is multivariate such as Z-score giving an estimate of the bankruptcy risk of the client. This kind of model helps the auditor to expand his or her ability to identify a financially distressed client. However, the auditor also makes use of plenty of non-financial information, such as managerial plans and reorganization actions, which are associated with avoiding the potential bankruptcy process that is going on. For a failing firm, this kind of information starts to flow immediately after the beginning of the failure (bankruptcy) process. There is a wide variety in the length of the failure process, typically from a couple of months (acute failure) to several years (chronic failure) [32]. In time, this process can take several alternative temporal forms such as do suddenly, gradually, or lingeringly failing firms [33]. This form affects the temporal accumulation (amount and timing) of non-financial information in different periods prior to bankruptcy. This kind of non-financial information is flowing until the bankruptcy date modifying continuously the estimate of the bankruptcy risk. However, the estimate given by the multivariate financial model is only based on the last financial statements and stays unchanged from the date of issue to the date of bankruptcy.

Figure 1 shows how the estimate of bankruptcy probability made by an auditor in GCO process develops until the failure (bankruptcy) date. The basis of the probability estimate is got from the financial prediction model calculated from the data received by the auditor at the date of preparing financial statements, $T_{F}$ days before bankruptcy. This probability estimate $P(F B)$ is constant from $T_{F}$ to the time of bankruptcy 0 . Thus, $T_{F}$ stands for the time distance between the 


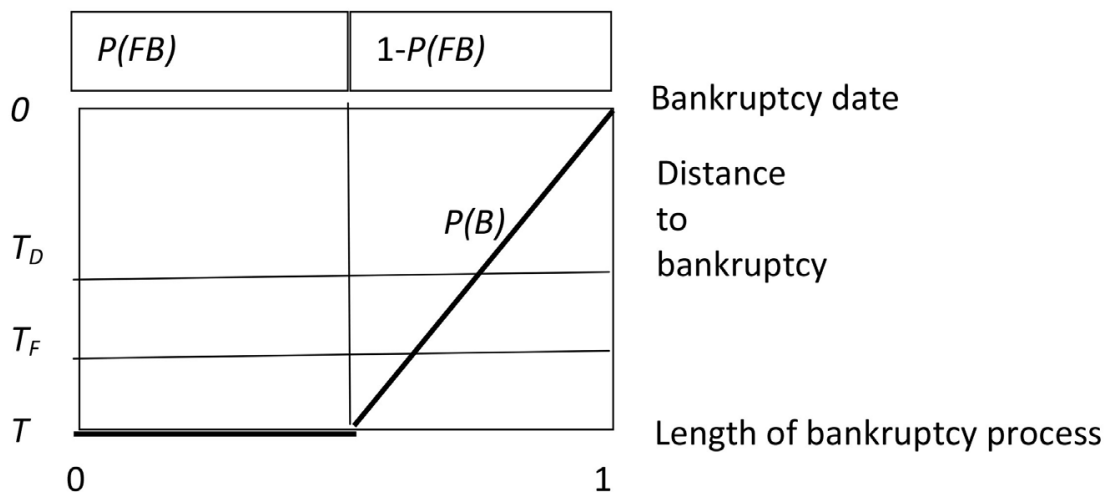

Figure 1. Development of the estimate of bankruptcy probability until the bankruptcy date. Legend: $P(F B)=$ Estimate of the bankruptcy probability based on last financial statements; $P(B)=$ Integrated estimate of the bankruptcy probability; $T_{D}=$ Time distance from issuing the audit report to the bankruptcy date; $T_{F}=$ Time distance from issuing last financial statements to the bankruptcy date.

preparation date and the time of bankruptcy. Similarly, $T_{D}$ stands for the time distance between the date of issuing the audit report and the time of bankruptcy. However, non-financial information of financial distress has begun to flow from the beginning of the failure process $T$ days before bankruptcy increasing the integrated bankruptcy probability estimate $P(B)$ continuously. This probability estimate $P(B)$ is based on both financial and non-financial information. At the time of bankruptcy $0, P(B)$ equals unity, since there is no uncertainty of the bankruptcy event. If it is assumed that the flow of non-financial information linearly increases $P(B)$ beginning from $T$ to 0 , then $P(B)$ at time $T_{D}$ can be presented as follows:

$$
\begin{aligned}
P(B) & =P(F B)+\frac{(1-P(F B))\left(T-T_{D}\right)}{T} \\
& =P(F B)+(1-P(F B))\left(1-\frac{T_{D}}{T}\right) \\
& =P(F B)+P(N F B)
\end{aligned}
$$

In this equation, the former term $P(F B)$ shows the impact of financial (statement) information on the estimate of bankruptcy probability at time $T_{D}$ while the latter term $P(N F B)$ presents the impact of non-financial information.

Let us assume that the estimate of the bankruptcy probability approximates the likelihood of the auditor to issue a GCO on the failing firm. The impact of financial information and the time distance to bankruptcy make the following marginal effects on the likelihood $P(B)$ :

$$
\begin{gathered}
\frac{\partial P(B)}{\partial P(F B)}=\frac{T_{D}}{T} \\
\frac{\partial P(B)}{\partial T_{D}}=-\frac{1-P(F B)}{T}
\end{gathered}
$$

Thus, the effect of $P(F B)$ on the likelihood to issue a GCO is positive and 
stronger, the longer is the time distance to bankruptcy $T_{D}$ in relation to $T$ (length of failure process). Similarly, the effect of $T_{D}$ on the likelihood is more negative, the lower is $P(F B)$.

The simplified model also allows us to calculate the ratio of the impact of $P(N F B)$ to the impact of $P(F B)$ in the following way:

$$
\frac{P(N F B)}{P(F B)}=\left[\frac{1}{P(F B)}-1\right]\left[1-\frac{T_{D}}{T}\right]=I R
$$

This equation thus describes the ratio of the non-financial information impact to the financial information impact. Since non-financial information is vaguer, more difficult to interpret, often contradictory, and sometimes weak, its interpretation is a challenging task for an auditor. Therefore, the ratio can be entitled here as inaccuracy ratio $I R$ such that the higher $I R$, the higher is inaccuracy associated with GCO issuing.

The marginal effects of $P(F B)$ and $T_{D}$ on $I R$ can be presented as follows:

$$
\begin{aligned}
\frac{\partial I R}{\partial P(F B)} & =\left[\frac{-1}{P(F B)^{2}}\right]\left[1-\frac{T_{D}}{T}\right] \\
\frac{\partial I R}{\partial T_{D}} & =\frac{-1}{T}\left[\frac{1}{P(F B)}-1\right]
\end{aligned}
$$

These results show firstly that the effect of $P(F B)$ on $I R$ is more negative, the lower is $P(F B)$ and the longer is $T_{D}$. Secondly, the effect of $T_{D}$ on $I R$ is more negative, the shorter is $T$ and the lower is $P(F B)$.

It is important to note that the time difference $T_{F}-T_{D}$ is of importance. In this time period from the date of preparing financial statements to the date of issuing the audit report, $P(F B)$ stays constant but $P(B)$ will anyway increase due to the flow of additional non-financial information. The longer the time difference is, the higher is the effect of non-financial information and thus $I R$. Since the additional non-financial information is more recent than financial information, the recency effect makes to the auditor the non-financial information more valuable than its real value. Because the additional non-financial information mainly includes negative messages from the failing process, the auditor further gives more additional value to this type of information. Therefore, the importance of non-financial information in GC judgment can be biased upwards. However, for failing firms it only increases the accuracy of estimate. For non-failing firms, it increases the likelihood of the Type II classification error when leading to misclassify some of them as failing firms.

Thus, the simplified description of the GC process shows that the approximated likelihood to issue a GCO on a failing firm is higher, the higher is the probability estimate given by the financial prediction model $P(F B)$ and the shorter is the time distance to bankruptcy $T_{D}$. The accuracy of the identifying a bankrupt firm is low, if $P(F B)$ is low and $T_{D}$ is long. In this situation, it can be difficult to make a correct GC judgment, although $P(B)$ may be upwards biased 
due to the recency effect and the negative-signals effect. Anyway, these biases may lead to an increased probability of Type II error. It is also important to notice that also $P(F B)$ may be inaccurate itself giving too low failure probability estimates for bankrupt firms. In general, the classification accuracy of bankruptcy prediction models using traditional methods (available to average auditors) is about $80-90 \%$ for a period of one year [1]. In addition, the time distance from $T_{F}$ (date of financial statement preparation) to 0 may weaken the accuracy. For a longer time distance (365 or more days), leverage (solidity) ratios are best predictors of bankruptcy, whereas for a shorter distance (such as less than 183 days), liquidity ratios play the dominant role [34]. Therefore, the choice of the financial prediction model should be related to the estimated stage of failure.

The analysis above gives rise for four different hypotheses $H 1$ a- $H 1 d$ presented in Figure 2. The hypotheses are as follows:

$H 1$ a: When the failure probability estimate given by the financial model $(P(F B))$ is high and the time distance to failure $\left(T_{D}\right)$ is long, the resulted accuracy of a GCO on failing firms is moderate.

$H 1 b$ : When the failure probability estimate given by the financial model $(P(F B))$ is high and the time distance to failure $\left(T_{D}\right)$ is short, the resulted accuracy of a GCO on failing firms is high.

$H 1 c$. When the failure probability estimate given by the financial model $(P(F B))$ is not high and the time distance to failure $\left(T_{D}\right)$ is long, the resulted accuracy of a GCO on failing firms is very low.

$H 1 d$ : When the failure probability estimate given by the financial model $(P(F B))$ is not high and the time distance to failure $\left(T_{D}\right)$ is short, the resulted accuracy of a GCO on failing firms is low.

Thus, it is expected that the two main dimensions, $P(F B)$ and $T_{D}$, mainly determine the accuracy of the GCO issued to failing firms (referring to Type I classification error).

If the clients are classified into four classes according to hypotheses $H 1 \mathrm{a}-H 1 \mathrm{~d}$, it is expected that there are auditor variables which within the classes explain the accuracy of GC decision making along $P(F B)$ and $T_{D}$. The decision to issue a GCO requires considerable auditor judgment ([3], p. 360). This judgment is largely based on the cognitive characteristics of the auditor, which can be classified into three types of variables: abilities, cognitive style, and strategy [9] [35]. In this classification, cognitive style entails distinctive ways of acquiring, storing,

\begin{tabular}{|l|l|l|}
\hline & $\begin{array}{l}\text { Long distance to bankruptcy } \\
\left(T_{D}\right)\end{array}$ & $\begin{array}{l}\text { Short distance to bankruptcy } \\
\left(T_{D}\right)\end{array}$ \\
\hline $\begin{array}{l}\text { High estimated financial risk } \\
(\mathrm{P}(\mathrm{FB}))\end{array}$ & $\begin{array}{l}\text { a) Hypothesis H1a: Moderate } \\
\text { prediction accuracy of GCO }\end{array}$ & $\begin{array}{l}\text { b) Hypothesis H1b: High } \\
\text { prediction accuracy of GCO }\end{array}$ \\
\hline $\begin{array}{l}\text { Not high estimated financial risk } \\
(\mathrm{P}(\mathrm{FB}))\end{array}$ & $\begin{array}{l}\text { c) Hypothesis H1c: Very low } \\
\text { prediction accuracy of GCO }\end{array}$ & $\begin{array}{l}\text { d) Hypothesis H1d: Low } \\
\text { prediction accuracy of GCO }\end{array}$ \\
\hline
\end{tabular}

Figure 2. Four different situations to issue a GCO for failing firms (Type I error rate). 
retrieving, and transforming information. The cognitive style can consist of two bipolar dimensions, perception and judgment ([9], p. 133). Perception is anchored by sensation and intuition, represents the way in which the auditor perceives incoming information. Sensors prefer facts while intuitives prefer possibilities. Judgment is anchored by thinking and feeling representing the method to arrive at a decision. Thinkers rely on rational processes of association whereas feelers use relational comparisons [9] [36].

Thus, dimensions perception and judgment make it possible to define four different cognitive styles for an auditor. There are two basic cognitive styles when the similar characteristics are combined. If the auditor at the same time prefers sensation and thinking, he/she can be regarded as an analytic individual by cognitive style. If the auditor simultaneously prefers intuition and feeling, he/she is an intuitive individual. However, if the cognitive style combines distinctive characteristic of the dimensions (sensation \& feeling; intuition \& thinking), the style is hybrid [9]. This kind of hybrid style can be regarded as a cognitive misfit that may impair the performance of the auditor [9] [10]. If an auditor is analytic, he/she prefers structural problems and routine precise work whereas an intuitive auditor prefers new and unstructured problems and often makes insightful decisions. If an analytic auditor is facing by new or unstructured problems or an intuitive auditor is facing by structural problems, there is a cognitive misfit and the resulted judgments may not be efficient.

The cognitive styles can be integrated in the present framework. Figure 3 presents hypotheses $\mathrm{H} 2 \mathrm{a}-\mathrm{H} 2 \mathrm{~d}$ which are drawn by combining the styles and the four GC judgment situations defined on the basis of $P(F B)$ and $T_{D}$. The situations

\begin{tabular}{|l|l|l|}
\hline & $\begin{array}{l}\text { Long distance to bankruptcy } \\
\left(T_{D}\right)\end{array}$ & $\begin{array}{l}\text { Short distance to bankruptcy } \\
\left(T_{D}\right)\end{array}$ \\
\hline $\begin{array}{l}\text { High estimated financial risk } \\
(\mathrm{P}(\mathrm{FB}))\end{array}$ & $\begin{array}{l}\text { a) } \\
\text { 1. High financial information } \\
\text { condition } \\
\text { 2. Low non-financial } \\
\text { information condition }\end{array}$ & $\begin{array}{l}\text { b) } \\
\text { 1. High financial information } \\
\text { condition } \\
\text { 2. High non-financial } \\
\text { information condition }\end{array}$ \\
& $\begin{array}{l}\text { Hypothesis H2a: Analytic } \\
\text { auditors perform better than } \\
\text { intuitive auditors }\end{array}$ & $\begin{array}{l}\text { Hypothesis H2b: Intuitive } \\
\text { auditors perform better than } \\
\text { analytic auditors }\end{array}$ \\
\hline $\begin{array}{l}\text { Not high estimated financial } \\
\text { risk } \\
(\mathrm{P}(\mathrm{FB}))\end{array}$ & $\begin{array}{l}\text { c) } \\
\text { 1. Low financial information } \\
\text { condition } \\
\text { 2. Low non-financial } \\
\text { information condition }\end{array}$ & $\begin{array}{l}\text { d) } \\
\text { 1. Low financial information } \\
\text { condition } \\
\text { (2. High/Low non-financial } \\
\text { information condition) }\end{array}$ \\
& $\begin{array}{l}\text { Hypothesis H2c: Misfit: } \\
\text { Analytical and intuitive } \\
\text { auditors perform equally }\end{array}$ & $\begin{array}{l}\text { Hypothesis H2d: Misfit: } \\
\text { Analytical and intuitive } \\
\text { auditors perform equally }\end{array}$ \\
\hline
\end{tabular}

Figure 3. Four different information conditions to issue a GCO for failing firms. 
strongly vary with respect to the nature and the amount of information acquired by the auditor in judgment. Firstly, when $P(F B)$ is high and $T_{D}$ is long, there are a lot of negative financial information but only little non-financial information that has accumulated thus far. Financial information is based on facts making it possible to use a structured and precise procedure in GC judgment. However, non-financial information is typically vague and unstructured. This kind of situation is desirable for an analytic auditor who then can beat intuitive auditors in predicting accuracy. Secondly, when $P(F B)$ is high and $T_{D}$ short, the present framework suggests that there is accumulated a lot of unstructured non-financial information along the structured financial information, which makes the situation desirable for an intuitive auditor. Thirdly, when $P(F B)$ is low and $T_{D}$ long, the situation is opposite: there is little negative financial evidence on potential bankruptcy but, at the same, only little accumulated non-financial information. This kind of situation is desirable to neither an analytical auditor nor an intuitive auditor and represents thus a misfit. It is obvious that the GCO accuracy is low for both cognitive types due to poor information condition and misfit.

Fourthly, when $P(F B)$ is low and $T_{D}$ short, there is little financial evidence. Since $P(F B)$ does not refer to a serious financial distress, also non-financial signals may be rather weak. The firms that behave in this way can be compared with the acute bankruptcy firms [32] or the suddenly failing firms [33]. In this kind of situation, auditors may perform better than in the previous situation but the information condition is not desirable for either of the cognitive types. In summary, the following hypotheses can be drawn:

H2a: When the failure probability estimate given by the financial model $(P(F B))$ is high and the time distance to failure $\left(T_{D}\right)$ is long, analytical auditors are more likely than intuitive auditors to issue GCOs to bankruptcy firms.

$H 2 b$ : When the failure probability estimate given by the financial model $(P(F B))$ is high and the time distance to failure $\left(T_{D}\right)$ is short, intuitive auditors are more likely than analytical auditors to issue GCOs to bankruptcy firms.

$H 2 c$. When the failure probability estimate given by the financial model $(P(F B))$ is not high and the time distance to failure $\left(T_{D}\right)$ is long, analytical and intuitive auditors are equally likely to issue GCOs to bankruptcy firms (misfit of cognitive style).

$H 2 d$ : When the failure probability estimate given by the financial model $(P(F B))$ is not high and the time distance to failure $\left(T_{D}\right)$ is short, analytical and intuitive auditors are equally likely to issue GCOs to bankruptcy firms (misfit of cognitive style).

Thus, it is expected that besides the main dimensions $P(F B)$ and $T_{D}$ which mainly determine the GC judgment situation, the fit of the cognitive style with the information condition impacts the accuracy of the GCO issued to bankruptcy firms (referring to Type I classification error). In such situations where $P(F B)$ is low, cognitive style is not expected to affect the accuracy due to misfit $(H 2 c \&$ $H 2 d)$. However, in those situations, other auditor characteristics like economic 
dependence on the client, auditor size, industry specialization, and compensation arrangements may play a role.

\section{Empirical Data and Methods}

Firstly, the purpose of the empirical part is to assess the four hypotheses H1a-H1d summarized in Figure 2. These hypotheses assume that differences in the estimated bankruptcy probability given by the financial prediction model $P(F B)$ and the time distance from the date of issuing the audit report to the bankruptcy date $T_{D}$ lead to differences in the GCO accuracy for failing firms. The empirical data, which are here used to test the hypotheses, include the last financial statements of 328 Finnish small and middle-sized firms (SMEs) bankrupted after 2010. These firms form a representative sample of Finnish bankrupt firms with respect to the size and industry. The data of the study are extracted from the Orbis database of Bureau Van Dijk (BvD) under a restriction that the selected firm must have an access to necessary audit variables used to test the hypotheses (see below). All these firms are limited companies.

In the last financial statements before bankruptcy the average net sales of the sample firms was 1197.23 Teur whereas the median was only 478.00 Teur. In these statements, the average total assets were only 468.37 Teur the median being 175.50 Teur. The majority of bankruptcy firms are very small. However, the largest firm reported the last net sales as 44,576.40 Teur. Thus, the size distribution is skewed as it is in the population of Finnish SMEs. The sample includes firms from several industries such as manufacturing, trade, construction, and transportation. The industry distribution of the sample firms is comparable with the population of Finnish bankruptcy firms. However, finance and insurance companies are excluded from the sample due to their special nature of auditing in Finland.

In Finland, a corporation is generally obliged to appoint an auditor and carry out audits in accordance with the Auditing Act. However, very small firms are not obliged to appoint an auditor if the size of the firm is below a certain threshold. In the present sample, all firms have appointed an auditor and carried out audits in accordance to the act, and their size structure statistically represent typical Finnish SMEs. The present sample does not include larger public firms, which have special requirements for auditing. Thus, the findings of the study are drawn for failing Finnish industrial small and middle-size limited companies. These kinds of failing firms may have special characteristics that make them different from large firms [37].

For this sample, $T_{D}$ and $P(F B)$ were calculated to allow classify the bankruptcy firms into the four classes as described in Figure 2. First, $T_{D}$ was calculated simply as the number of days from the day issuing the audit report to the day of bankruptcy. The median value of $T_{D}$ in the present sample was 215.5 days that makes more than seven months. Secondly, the estimate of $P(F B)$ was measured by the logistic bankruptcy prediction model estimated by Laitinen and Laitinen 
([38], p. 174) using Finnish data from small and middle-size firms (SMEs). The coefficients of this model are estimated by the logistic regression analysis (LRA) based on the data from about 60,000 non-bankrupt SMEs and about 500 bankrupt SMEs approximately for one year prior to bankruptcy. This model is suitable for using to estimate $P(F B)$, since the firms in these data are similar to the firms in the present sample. The logit $(L)$ of the model is calculated as follows:

$$
L=0.843-0.027 \cdot E R-0.039 \cdot Q R-0.01 \cdot C F
$$

where:

$E R=$ the equity ratio (\%)

$Q R=$ the quick ratio

$C F=$ the traditional cash flow/net sales (\%)

This logit is used to calculate the conditional probability of bankruptcy as $P(F B)=1 /\left(1+e^{-L}\right)$. The estimation was carried out as weighted to give equal weights for non-bankrupt and bankrupt firms. Therefore, the critical cut-off value of $P(F B)$ is 0.5 . For this cut-off value, the classification accuracy of the prediction model even for very small firms was excellent ([38], p. 174). In the test data, the rate of correct classification for small bankrupt firms was $82.6 \%$ one year prior to bankruptcy. The median value of $P(F B)$ in the present sample of 328 bankruptcy firms was 0.82 that clearly exceeds the cut-off value.

Secondly, the purpose is to assess empirically the hypotheses $H 2 a-H 2 d$ using a set of auditor variables. In the 328 sample firms, 172 auditors were auditing the last financial year. Thus, the average number of bankruptcy firms per auditor is less than two (1.9). However, as many as 92 of 172 auditors (53.5\%) had acted as an auditor only in one bankrupt firm. The low average number of bankruptcies per auditors is in line with the general frequency of bankruptcies in Finland, yearly $1 \%-2 \%$ of firms (Statistics Finland: Bankruptcy Statistics). Panel 1 of Appendix 1 presents the eighteen auditor variables used in the study. Most variables are collected from the Finnish Chamber of Commerce (FCC) material consisted of quality assurance reviews for the auditors of the bankruptcy firms. However, the salary information from the review year is received from Veropörssi (a company selling taxation information). The data received from FCC do not include audit firms auditing public interest entities, which excludes for example all Big 4 firms from the data. The data however include auditors from a number of smaller audit firms in addition to (individual) private auditors. The variables in the data include the final result of a peer review given on a four-grade scale 1 - 4 where 1 stands for failing the peer review and 4 for no deficiencies in audit work.

Furthermore, the data include measures for the level of compliance (\%) with International Standards on Auditing (ISA) assessed for four audit areas (Planning, Analytic procedure 1, Analytic procedure 2, and Conclusion) in peer review. ISA 570 (Going concern assessment) is included in the part Analysis 2. This means that in peer review audit quality evaluation peer reviewer is monitoring if peer reviewed auditor has complied with ISAs. If an auditor has not 
complied with ISA standards in his/her engagements, it will lead to low quality in audit quality measure. In this review, detailed questions in the peer review are used to determine the level of compliance of ISA. Hypotheses $H 2 a-H 2 d$ are associated with the effects of the cognitive style on the GCO accuracy. Therefore, the bipolar intuitive-analytic dimension is measured here by the degree of compliance with the ISA standards in auditors' use of analytic procedures in peer review. The higher the compliance with the analytic standards, the higher is the analytic strait of the auditor. These measures vary from 0 to $100 \%$ so that the average values in the sample are $69.1 \%$ (part 1) and 73.2\% (part 2). These measures for the intuitive-analytic dimension have a low negative correlation with experience $(-0.15 \&-0.00)$, a low positive correlation with the tier of the auditor $(0.02 \& 0.09)$, but a very high positive correlation with the final grade of the review $(0.68 \& 0.65)$.

It should be noted that The Finnish Auditing Act does not include the clear concept of Going Concern opinion. However, $15 \S$ obliges auditors to disclose all the necessary information in the audit opinion. Furthermore, the associations of KHT (first tier) and HTM (second tier) auditors in Finland recommend that all auditors in Finland ought to comply with ISAs and thus also ISA 570. Hence, practically auditors should report if the ability of the entity to continue as a Going concern is compromised. The opinions that have a statement (modification) about negative equity and reorganization in GCOs were added to ones that have a precise statement about the ability of the firm to continue as a Going concern. Thus, slightly over half of the opinions (54.6\%) are GC modified, which is in line with previous studies from other countries. Carson, Fargher, Geiger, Lennox, Raghunandan \& Willekens ([3], p. 357) show statistics that U.S. opinions modified for GC uncertainties 2000-2010 on bankrupt firms have been on average $60.1 \%$. However, the range of the percentage annually varied from $40.0 \%$ (2000) to $81.5 \%$ (2009).

The hypotheses of the study are tested using simple statistical methods. Firstly, hypotheses $H 1 \mathrm{a}-H \mathrm{l} d$ were assessed classifying the bankrupt sample firms into four groups according to whether or not they exceed the median values of $P(F B)$ (0.82) and $T_{D}$ (215.5). Then, conforming to the order of hypotheses $H 1$ a- $H 1 d$ the four groups of firms were organized as follows:
a) high $P(F B) \&$ long $T_{D}$,
b) high $P(F B) \&$ short $T_{D}$,
c) not high $P(F B) \&$ long $T_{D}$, and
d) not high $P(F B) \&$ short $T_{D}$.

Appendix 1 presents the median values of a set of traditional financial ratios in these four groups to describe the financial situation of the client firms. These financial ratios are reported from Voitto+ database of Suomen Asiakastieto Oy (https://www.asiakastieto.fi/voitto/ohje/tunnusluvut eng.htm\#gearing). The set of ratios also includes $E R, Q R$, and $C F$ used in the logistic model.

Then, the percentage of the firms receiving a GCO (accuracy of GCOs) was 
calculated for each of the four groups. Finally, the differences in the percentages between the groups were tested statistically pairwise by the pairwise test of proportions. Secondly, hypotheses $H 2 a-H 2 d$ on the effect of the cognitive style of the auditor were statistically tested by the 1-tailed Chi-Square median test on the differences in the compliance measures (analysis 1 and analysis 2 parts) between the firms received a GCO and the firms not received a GCO. Since the distributions of the variables did not conform to the normal distribution in the groups of firms, a nonparametric statistical test was used. In the same way, the statistical significance of the differences in the auditor control variables between the classes of GCO was assessed. The description of these control variables is presented in Appendix 2.

\section{Empirical Results}

\subsection{Hypotheses $\mathrm{H} 1 \mathrm{a}-\mathrm{H} 1 \mathrm{~d}$}

Panel 1 of Table 1 presents the percentage of the bankrupt sample firms received

Table 1. The percentage of the bankrupt firms received a going-concern audit opinion (GCO) by groups. (a) Panel 1. Percentages by groups; (b) Panel 2. Groupwise comparison of percentages for firms with GCO.

(a)

\begin{tabular}{ccccc}
\hline & Group 1 & Group 2 & Group 3 & Group 4 \\
\hline & $\begin{array}{c}\text { High } P(F B) \& \\
\text { Long } T_{D}\end{array}$ & $\begin{array}{c}\text { High } P(F B) \& \\
\text { Short } T_{D}\end{array}$ & $\begin{array}{c}\text { Not high } P(F B) \& \text { Not high } P(F B) \& \\
\text { Long } T_{D}\end{array}$ & \begin{tabular}{c} 
Short $T_{D}$ \\
\hline Firms received GCO:
\end{tabular} \\
Median of $P(F B)$ & 0.9500 & 0.9500 & 0.7000 & 0.7200 \\
Median of $T_{D}$ & 304.59 & 121.82 & 307.17 & 115.27 \\
Number of firms & 49 & 77 & 23 & 30 \\
Percentage of firms & 0.7101 & 0.8105 & 0.2421 & 0.4348 \\
Firms received not GCO: & & & & 0.6100 \\
Median of $P(F B)$ & 0.9500 & 0.9500 & 0.5500 & 122.87 \\
Median of $T_{D}$ & 293.50 & 137.78 & 345.63 & 39 \\
Number of firms & 20 & 18 & 72 & 0.5652 \\
\hline Percentage of firms & 0.2899 & 0.1895 & 0.7579 & \\
\hline
\end{tabular}

(b)

\begin{tabular}{lcc}
\hline & $Z$ test statistic & $p$-value \\
\hline Group 1 \& Group 2 & -11.2690 & 0.0000 \\
Group 1 \& Group 3 & 37.9795 & 0.0000 \\
Group 1 \& Group 4 & 19.4076 & 0.0000 \\
Group 2 \& Group 3 & 54.1500 & 0.0000 \\
Group 2 \& Group 4 & 33.1146 & 0.0000 \\
Group 3 \& Group 4 & -16.1056 & 0.0000 \\
\hline
\end{tabular}


a GCO and statistical information of $P(F B)$ and $T_{D}$ by groups. In the first group, the median $P(F B)$ for the firms with and without GCO is 0.95 ( $p$-value of the median test is 0.9391 ) referring to a very high financial distress in both classes. The median value of $T_{D}$ for the firms without GCO is 293.5 days and for the firms with GCO 304.6 days ( $p$-value 0.6523 ) referring to a long time distance. In this group, the percentage of the firms received GCO is $71.01 \%$ that clearly exceeds the average of the whole sample (54.57\%). Thus, the percentage is moderate supporting $H 1$ a. In the second group, the medians of $P(F B)$ are also 0.95 ( $p$-value 0.6372 ) whereas the medians of $T_{D}$ are significantly lower, being 137.8 days for the firms without GCO and 121.8 days for the firms with GCO ( $p$-value $0.5685)$. For this group, the percentage of the firms received GCO is as high as $81.05 \%$. Thus, for the group with a high $P(F B)$ but a short $T_{D}$ the percentage or the accuracy of GCO is high which gives support to $H \mathrm{l} b$. Panel 2 of Table 1 shows that the difference in the percentage between the groups 1 and 2 is statistically significant.

In the third group, the median of $P(F B)$ is 0.55 for the firms without GCO and 0.70 for the firms with GCO ( $p$-value 0.0003) emphasizing the effect of $P(F B)$ in this group. The median values however clearly exceed the cut-off value of $P(F B)$ (0.50) giving thus a signal of serious distress. Similarly, the medians of $T_{D}$ differ from each other between the classes ( $p$-value 0.1074 ) being 345.6 days for the firms without GCO and 307.2 days for those with GCO. For this group of a not high $P(F B)$ and a long $T_{D}$ the percentage of the firms with GCO is very low (24.21\%) indicating a very low accuracy of GCO and clearly supporting Hlc. This percentage differs statistically very significantly from those of groups 1 and 2 (Panel 2). In the fourth group, the medians of $P(F B)$ similarly differ by the classes ( $p$-value 0.0001 ) so that it is 0.72 for the firms with GCO and much lower for those without GCO only 0.61 . However, the medians of $T_{D}$ do not differ significantly between the classes being 122.9 days for the firms without GCO and 115.3 days for those with GCO ( $p$-value 0.7059 ). The percentage of the firms received GCO is clearly higher than the percentage in group 3 but lower than in groups 1 and 2 (Panel 2). Thus, the percentage of the accuracy of GCO is low being lower than the median of the whole sample supporting $H 1 d$.

\subsection{Hypotheses $\mathrm{H} 2 \mathrm{a}-\mathrm{H} 2 \mathrm{~d}$}

Table 2 presents the median values for the auditor variables by GCO classes and groups (for the binary variables means are displayed). In group 1 (high $P(F B)$ and long $\left.T_{D}\right)$, the medians of the compliance measures for analysis part 1 and 2 are clearly higher in firms which received a GCO $(84.6 \& 84.5)$ than in the firms that did not receive it $(65.3 \& 77.47)$. Although the statistical significance is not very high for the differences in the variables ( $p$-values $0.066 \& 0.104$ ), empirical evidence clearly supports $H 2 \mathrm{a}$ assuming that analytic auditors perform better than intuitive auditors do in GCO accuracy. There are also other significant differences in the auditor variables between the GCO classes. The auditors issuing a 
Table 2. Medians of the auditor variables\#.

\begin{tabular}{|c|c|c|c|c|c|c|c|c|c|c|c|c|}
\hline & \multicolumn{2}{|l|}{ Group 1} & \multicolumn{3}{|c|}{ Group 2} & \multicolumn{3}{|c|}{ Group 3} & \multicolumn{3}{|c|}{ Group 4} & \multirow[b]{2}{*}{$p$-values } \\
\hline & No GCO & $\begin{array}{c}\text { Yes } \\
\text { GCO }\end{array}$ & $p$-values & $\begin{array}{c}\text { No } \\
\text { GCO }\end{array}$ & $\begin{array}{c}\text { Yes } \\
\text { GCO }\end{array}$ & $p$-value & $\begin{array}{l}\text { No } \\
\text { GCO }\end{array}$ & $\begin{array}{c}\text { Yes } \\
\text { GCO }\end{array}$ & $p$-value $\$$ & $\begin{array}{c}\text { No } \\
\text { GCO }\end{array}$ & $\begin{array}{c}\text { Yes } \\
\text { GCO }\end{array}$ & \\
\hline Auditor gender* & 0.80 & 0.80 & 0.4849 & 0.83 & 0.83 & 0.4912 & 0.81 & 0.87 & 0.2440 & 0.85 & 0.80 & 0.3093 \\
\hline Auditor quality grade & 2.25 & 3.00 & 0.1642 & 3.00 & 2.00 & 0.0660 & 2.00 & 2.00 & 0.2511 & 2.00 & 2.00 & 0.3543 \\
\hline Auditor tier* & 0.10 & 0.16 & 0.2507 & 0.39 & 0.27 & 0.1665 & 0.29 & 0.43 & 0.1025 & 0.38 & 0.23 & 0.0923 \\
\hline Legal entity* & 0.20 & 0.18 & 0.4379 & 0.11 & 0.14 & 0.3628 & 0.14 & 0.22 & 0.1856 & 0.21 & 0.13 & 0.2194 \\
\hline Working type ${ }^{*}$ & 0.65 & 0.61 & 0.3853 & 0.67 & 0.57 & 0.2310 & 0.56 & 0.70 & 0.1185 & 0.54 & 0.77 & 0.0261 \\
\hline Number of engagements annually & 179.5 & 145.0 & 0.2702 & 212.0 & 130.0 & 0.1376 & 118.0 & 150.0 & 0.3836 & 108.0 & 150.0 & 0.2786 \\
\hline Number of hours on engagements & 754.0 & 800.0 & 0.3262 & 1003.0 & 642.0 & 0.1376 & 804.0 & 760.0 & 0.3066 & 465.0 & 805.0 & 0.0604 \\
\hline Number of hours per engagement & 3.25 & 3.80 & 0.3262 & 3.70 & 3.60 & 0.4801 & 3.45 & 3.60 & 0.3824 & 3.40 & 4.40 & 0.0059 \\
\hline Auditor age & 62.00 & 61.00 & 0.3386 & 60.00 & 59.00 & 0.4092 & 60.00 & 58.00 & 0.2483 & 60.00 & 58.00 & 0.2249 \\
\hline Years after auditor exam & 25.00 & 23.00 & 0.1859 & 21.50 & 21.00 & 0.4332 & 25.00 & 24.00 & 0.4272 & 24.00 & 24.00 & 0.4442 \\
\hline Taxable salary (annual) & 28,517 & 58,011 & 0.0663 & 40,137 & 48,882 & 0.0651 & 45,238 & 52,948 & 0.1058 & 51,555 & 44,303 & 0.1903 \\
\hline Capital gain (annual) & 2248 & 2071 & 0.4696 & 0 & 2476 & 0.0651 & 1591 & 1782 & 0.4447 & 612 & 541 & 0.3529 \\
\hline Total salary (annual) & 41,806 & 66,610 & 0.0663 & 42,051 & 55,000 & 0.0651 & 46,832 & 62,770 & 0.0422 & 53,603 & 52,820 & 0.4583 \\
\hline Number of hours on audit courses & 24.50 & 10.00 & 0.1292 & 6.50 & 0.00 & 0.4803 & 0.00 & 7.00 & 0.0548 & 14.00 & 0.00 & 0.3529 \\
\hline Compliance: planning & 91.45 & 91.61 & 0.4774 & 88.28 & 90.91 & 0.1605 & 88.89 & 85.16 & 0.2519 & 68.75 & 88.31 & 0.2786 \\
\hline Compliance: analytical procedure 1 & 65.32 & 84.62 & 0.0663 & 81.25 & 72.73 & 0.1376 & 78.28 & 60.27 & 0.2556 & 75.00 & 72.92 & 0.4583 \\
\hline Compliance: analytical procedure 2 & 77.47 & 84.52 & 0.1040 & 83.73 & 73.66 & 0.0108 & 77.32 & 77.78 & 0.3836 & 77.32 & 78.93 & 0.3608 \\
\hline Compliance: conclusions & 91.57 & 95.83 & 0.0211 & 91.90 & 91.30 & 0.2822 & 91.51 & 88.64 & 0.4283 & 91.30 & 93.19 & 0.1425 \\
\hline
\end{tabular}

Legend: ${ }^{*}=$ Mean instead of median displayed; \# = For the scales of variables see Appendix $1 ; \S=1$-tailed Chi-Square median test.

GCO have a higher degree in compliance with conclusions standards and they get higher income than the auditors not issuing a GCO do get.

In group 2 (high $P(F B)$ and short $T_{D}$ ) the relationships between the intuitive-analytic dimension and the GC prediction accuracy are opposite. The medians of the analysis compliance measures are significantly lower in the class of issuing a GCO (72.7 \& 73.7) than in that of not issuing a GCO (81.3 \& 83.7). Thus, empirical evidence for group 2 supports hypothesis $H 2 b$ assuming that in this situation intuitive auditors perform better than analytic auditors do. Moreover, the auditors issuing a GCO, usually have got a lower grade in the peer review assessment and higher income than the auditors not issuing a GCO. Thus, in both groups 1 and 2 the auditors, who have given a GCO to bankrupt firms, tend to have a higher income level irrespective of the cognitive style.

In group 3 (low $P(F B)$ and long $T_{D}$ ) where the GCO accuracy is lowest, the compliance measures of analysis parts 1 and 2 do not in a statistically significant way differ between the GCO classes. This finding supports hypothesis $H 2 c$ that assumes that the cognition style does not affect GCO prediction accuracy. However, the median for the compliance of analytical part 1 is very low (60.3) for the 
auditors issuing a GCO compared with median in another class (78.3). The relationship is anyway so unsystematic that the difference is not statistically significant ( $p$-value 0.256 ). The auditors issuing a GCO have also in this group a higher income than the auditors in the other class do. Moreover, they are more often Tier 1 (KHT) auditors working full-time.

In group 4 (low $P(F B)$ and short $T_{D}$ ) where the GCO accuracy is low, the differences in the medians of the analysis compliance measures are not statistically significant. This result obviously supports hypothesis $H 2 d$ that assumes that both cognition styles perform equally in this situation. For the auditors not issuing a GCO the median of the compliance measure for part planning is exceptionally low (68.8) as compared with the median in the other class (88.3). However, the relationship is unsystematic and thus not statistically significant. In this group, the relationship between the auditors' income and the class of GCO is not significant as it is in other groups. However, the auditors issuing a GCO in this group are more often lower tier (HTM) and full-time working auditors who spend more time annually on engagements in general and more hours per engagement than their counterparts who do not issue a GCO in this situation.

\section{Conclusions}

The GC judgment is an important audit issue that has been intensively investigated from several points of view. In this study, the focus was set on two related questions about the accuracy of the GC judgment in considering a failing client that will bankrupt. Thus, this study concentrates on the classification Type I error and its determinants. Firstly, it was hypothesized that a good explanation for the variation in the accuracy can be drawn from the situation of the client before bankruptcy. It was assumed that there are two main variables that determine the characteristics of the situation in terms of GC prediction accuracy. These variables were the estimated financial risk and the time distance to bankruptcy. The dimensions anchored by not high—high financial risk and by short-long time distance made it possible to classify clients into four different groups. It was expected that the group of clients with high financial risk and short time distance is most accurate to judge right in GC. However, it was also expected that the group of clients with not high financial risk and long time distance to bankruptcy is least accurate to do so. The rest combinations of the dimensions were less accurate to judge than the former group but more accurate to judge than the latter group.

The hypotheses were assessed by empirical data from 328 Finnish small bankrupt firms. Empirical evidence supported the research hypotheses. The differences in the prediction accuracy between the groups describing the GC situation before bankruptcy were statistically very significant. In the group with high financial risk and short time distance to bankruptcy the percentage of the firms received a GCO was $81.1 \%$ whereas in the group with not high financial risk and long time distance it was only $24.2 \%$. On average, the prediction accuracy of is- 
suing GCO was $54.6 \%$ that corresponds to the percentages often got in previous studies [2] [3]. Thus, the results indicate that the variation in the prediction accuracy of GC judgment found in prior studies can be a result of a variation in the financial risk and time distance to bankruptcy in the sample of failing clients.

Secondly, it was hypothesized that the accuracy of GC judgment is also related to the fit between the situation of the client before bankruptcy and the cognitive style of the auditor. If there is a misfit, the performance in predicting is assumed to impair [9] [10]. It was assumed that in the situation with high financial risk and long time distance analytic auditors perform better than intuitive auditors do due to the structured nature of information. However, it was hypothesized that in the situation with high financial risk and long time distance intuitive auditors perform better than analytic ones because of the accumulation of unstructured non-financial information. Other groups were considered as undesirable for both cognitive types.

These hypotheses were tested by the aforementioned data. There were in all 172 auditors who had acted as the last auditors in the data from 328 failing client firms. Empirical evidence supported the hypotheses showing that the fit between the client situation (task) and the cognitive style was an important factor affecting the GCO issuing accuracy. These findings implicate that to financially high-risk clients it would be useful to estimate the time distance to the potential bankruptcy. This distance is related to the nature of information that the auditor is receiving for GC judgment. If there is a plenty of non-financial unstructured information, an intuitive auditor seems to perform better than an analytic one. However, if the information mainly consists of structured financial information, an analytic auditor can perform well. In situation where the financial risk of the client is not high, the cognitive style does not play an important role. In addition, the variation in issuing accuracy of GCO in prior studies may be related to the variation in the cognitive styles of the auditors in the sample.

The analysis of the auditor variables gave interesting additional findings. In three groups, the income of the auditor was usually higher for those auditors who issued a GCO to the bankrupt client. This finding can refer to the effect created by economic independence from the client [3]. It indicates that income is related to audit quality as defined as the accuracy of GC judgment, client situation, and auditors' cognitive style judgment. The group with not high financial risk and short time distance was the only group where this income effect was not identified. However, in this group the tier of the auditor, full-time working, and spending more time on engagement in general and in special more hours per engagement were related to better performance.

In summary, this study contributes to the auditing research being the first approach that systematically investigates the relationship between financial risk, distance to bankruptcy, and cognitive style on GC judgment in an archival research. It contributes to the research when showing that an auditor's accuracy in issuing a GCO largely depends on estimated financial risk of the client, time to 
bankruptcy, and the fit between her or his cognitive style and the characteristics of the issuing situation. Thus, this research has produced new and interesting findings about the accuracy of GC judgment. However, it is also subject to some limitations that should be solved in future research. Firstly, the study sample consisted of very small firms that can have peculiar characteristics that differ them from larger firms. In future studies, larger firms should be studied as well. Secondly, the present sample only included bankrupt firms to focus on the classification Error Type 1. In future, also acting (Going concern) firms should be investigated. Thirdly, the auditors in the sample do not audit public companies, which excluded Big 4 auditors from the study. Therefore, in further studies, these auditors should also be studied.

Fourthly, in this study only a rough classification with respect to financial risk and time distance to bankruptcy has been applied resulting in only four groups. In further studies, it would be fruitful to use a larger sample and more sophisticated classification. Fifthly, the dimension anchored by intuitive-analytic is measured by the auditor's compliance with ISA standards on the analytic procedures in peer review. In future, personality tests could also be used to measure this dimension. Finally, further studies could apply more advanced statistical methods than used here, to show the relationship between GC prediction accuracy, client situation, and auditors' cognitive style.

\section{Conflicts of Interest}

The authors declare no conflicts of interest regarding the publication of this paper.

\section{References}

[1] Bellovary, J.L., Ciacomino, D.W. and Akers, M.D. (2007) A Review of Going Concern Prediction Studies: 1976 to Present. Journal of Business and Economics Research, 5, 9-28. https://doi.org/10.19030/jber.v5i5.2541

[2] Gissel, J.L., Robertson, J.C. and Stefaniak, C.M. (2010) Formation and Consequences of Going Concern Opinions: A Review of the Literature. Journal of Accounting Literature, 29, 59-141.

[3] Carson, E., Fargher, N.L., Geiger, M.A., Lennox, C., Raghunandan, K. and Willekens, M. (2013) Audit Reporting for Going-Concern Uncertainty: A Research Synthesis. Auditing. A Journal of Practice and Theory, 32, 353-384.

https://doi.org/10.2308/ajpt-50324

[4] Louwers, T.J. (1998) The Relationship between Going-Concern Opinions and the Auditor's Loss Function. Journal of Accounting Research, 36, 143-156.

https://doi.org/10.2307/2491325

[5] Libby, R. and Frederick, D.M. (1990) Experience and the Ability to Explain Audit Findings. Journal of Accounting Research, 28, 348-367. https://doi.org/10.2307/2491154

[6] Abdolmohammadi, M. and Wright, A. (1987) An Examination of the Effects of Experience and Task Complexity on Audit Judgments. The Accounting Review, 62, $1-13$. 
[7] Bonner, S.E. (1994) A Model of the Effects of Audit Task Complexity. Accounting, Organizations and Society, 19, 213-234. https://doi.org/10.1016/0361-3682(94)90033-7

[8] Bonner, S.E. (2008) Judgment and Decision Making in Accounting. Prentice Hall, Upper Saddle River.

[9] Fuller, L.R. and Kaplan, S.E. (2004) A Note about the Effect of Auditor Cognitive Style on Task Performance. Behavioral Research in Accounting, 16, 131-143. https://doi.org/10.2308/bria.2004.16.1.131

[10] Chan, D. (1996) Cognitive Misfit of Problem-Solving Style at Work: A Facet of Person-Organization Fit. Organizational Behavior and Human Decision Processes, 68, 194-207. https://doi.org/10.1006/obhd.1996.0099

[11] Menon, K. and Schwartz, K. (1987) An Empirical Investigation of Audit Qualification Decisions in the Presence of Going Concern Uncertainties. Contemporary Accounting Research, 3, 302-315. https://doi.org/10.1111/j.1911-3846.1987.tb00640.x

[12] Koh, H.C. and Killough, L.N. (1990) The Use of Multiple Discriminant Analysis in the Assessment of the Going-Concern Status of an Audit Client. Journal of Business Finance and Accounting, 17, 179-192. https://doi.org/10.1111/j.1468-5957.1990.tb00556.x

[13] Altman, E.I. and McGough, T. (1974) Evaluation of a Company as a Going Concern. Journal of Accountancy, 138, 50-57.

[14] Mutchler, J.F. (1985) A Multivariate Analysis of the Auditor's Going-Concern Opinion Decision. Journal of Accounting Research, 23, 668-682.

https://doi.org/10.2307/2490832

[15] Geiger, M.A. and Raghunandan, K. (2002) Auditor Tenure and Audit Reporting Failures. Auditing. A Journal of Practice and Theory, 21, 67-78. https://doi.org/10.2308/aud.2002.21.1.67

[16] LaSalle, R. and Anandarajan, A. (1996) Auditors' Views on the Type of Audit Report Issued to Entities with Going Concern Uncertainties. Accounting Horizons, $10,51-72$.

[17] Asare, S.K. (1990) The Auditor's Going Concern Decision: A Review and Implications for Future Research. Journal of Accounting Literature, 9, 39-64.

[18] Bell, T.B. and Tabor, R.H. (1991) Empirical Analysis of Audit Uncertainty Qualifications. Journal of Accounting Research, 29, 350-370. https://doi.org/10.2307/2491053

[19] Koh, H.C. (1991) Model Predictions and Auditor Assessments of Going Concern Status. Accounting and Business Research, 21, 331-338. https://doi.org/10.1080/00014788.1991.9729848

[20] Behn, B.K., Kaplan, S.E. and Krumwiede, K.R. (2001) Further Evidence on the Auditors' Going Concern Report: The Influence of Management Plans. Auditing. A Journal of Practice and Theory, 20, 13-29. https://doi.org/10.2308/aud.2001.20.1.13

[21] Riley, R., Behn, B.K. and Pany, K. (2000) Management Plans and SAS No. 59 Going Concern Resolutions. Advances in Accounting, 17, 187-203. https://doi.org/10.1016/S0882-6110(00)17011-7

[22] Biggs, S.F., Selfridge, M. and Krupka, G.R. (1993) A Computational Model of Auditor Knowledge and Reasoning Processes in the Going-Concern Judgment. Auditing. A Journal of Practice and Theory, 12, 82-99.

[23] Arnold, V., Collier, P.A., Leech, S.A. and Sutton, S.G. (2001) The Impact of Political Pressure on Novice Decision Makers: Are Auditors Qualified to Make Going Con- 
cern Judgments? Critical Perspectives on Accounting, 12, 323-338. https://doi.org/10.1006/cpac.2000.0442

[24] Choo, F. (1996) Auditors' Knowledge Content and Judgment Performance: A Cognitive Script Approach. Accounting, Organizations and Society, 21, 339-359. https://doi.org/10.1016/0361-3682(95)00048-8

[25] Reichelt, K.J. and Wang, D. (2010) National and Office-Specific Measures of Auditor Industry Expertise and Effects on Audit Quality. Journal of Accounting Research, 48, 647-686. https://doi.org/10.1111/j.1475-679X.2009.00363.x

[26] Lehmann, C.M. and Norman, C.S. (2006) The Effects of Experience on Complex Problem Representation and Judgment in Auditing: An Experimental Investigation. Behavioral Research in Accounting, 1, 65-83. https://doi.org/10.2308/bria.2006.18.1.65

[27] Joe, J.R. (2003) Why Press Coverage of a Client Influences the Audit Opinion. Journal of Accounting Research, 41, 109-133. https://doi.org/10.1111/1475-679X.00098

[28] Firth, M., Mo, P. and Wong, R. (2012) Auditors' Organizational Form, Legal Liability and Reporting Conservatism: Evidence from China. Contemporary Accounting Research, 29, 57-93. https://doi.org/10.1111/j.1911-3846.2011.01081.x

[29] Favere-Marchesi, M. (2006) “Order Effects" Revisited: The Importance of Chronology. Auditing: A Journal of Practice and Theory, 25, 69-83. https://doi.org/10.2308/aud.2006.25.1.69

[30] Guiral, A. and Esteo, F. (2006) Are Spanish Auditors Skeptical in Going Concern Evaluations? Managerial Auditing Journal, 21, 598-620. https://doi.org/10.1108/02686900610674889

[31] Ashton, R.H. and Kennedy, J. (2002) Eliminating Recency with Self Review: The Case of Auditors “Going Concern” Judgments. Journal of Behavioral Decision Making, 15, 221-231. https://doi.org/10.1002/bdm.412

[32] Laitinen, E.K. (1991) Financial Ratios and Different Failure Processes. Journal of Business Finance and Accounting, 18, 649-673. https://doi.org/10.1111/j.1468-5957.1991.tb00231.x

[33] D’Aveni, R. (1989) The Aftermath of Organizational Decline: A Longitudinal Study of the Strategic and Managerial Characteristics of Declining Firms. Academy of Management Journal, 32, 577-605. https://doi.org/10.2307/256435

[34] Sormunen, N. and Laitinen, T. (2012) Late Financial Distress Process Stages and Financial Ratios: Evidence for Auditors' Going Concern Evaluation. Finnish Journal of Business Economics, 1, 41-69.

[35] Ho, J.L. and Rodgers, W. (1993) A Review of Accounting Research on Cognitive Characteristics. Journal of Accounting Literature, 12, 101-130.

[36] Myers, I. and McCaulley, M. (1985) Manual a Guide to the Development and Use of the Myers-Briggs Type Indicator. Consulting Psychologists Press, Inc., Palo Alto.

[37] Altman, E.I., Sabato, G. and Wilson, N. (2010) The Value of Non-Financial Information in Small and Medium-Sized Enterprise Risk Management. The Journal of Credit Risk, 6, 1-33. https://doi.org/10.21314/JCR.2010.110

[38] Laitinen, T. and Laitinen, E.K. (2014) Yrityksen maksukyky-Arviointi ja ennakointi. KHT-media. Helsinki. Printed by Bookwell Oy. Porvoo. (In Finnish) 


\section{Appendices}

\section{Appendix 1. Medians of the Target Bankrupt Client Variables (Last Financial Statements)}

\begin{tabular}{|c|c|c|c|c|c|c|c|c|c|c|c|c|}
\hline & \multicolumn{3}{|c|}{ Group 1} & \multicolumn{3}{|c|}{ Group 2} & \multicolumn{3}{|c|}{ Group 3} & \multicolumn{3}{|c|}{ Group 4} \\
\hline & $\begin{array}{c}\text { No } \\
\text { GCO }\end{array}$ & $\begin{array}{c}\text { Yes } \\
\text { GCO }\end{array}$ & $p$-value $\$$ & $\begin{array}{c}\text { No } \\
\text { GCO }\end{array}$ & $\begin{array}{c}\text { Yes } \\
\text { GCO }\end{array}$ & $p$-values & $\begin{array}{c}\text { No } \\
\text { GCO }\end{array}$ & $\begin{array}{c}\text { Yes } \\
\text { GCO }\end{array}$ & $p$-value $\$$ & $\begin{array}{c}\text { No } \\
\text { GCO }\end{array}$ & $\begin{array}{c}\text { Yes } \\
\text { GCO }\end{array}$ & $p$-values \\
\hline Net sales (Teur) & 368.00 & 313.90 & 0.1273 & 465.00 & 480.35 & 0.5000 & 575.00 & 652.00 & 0.3804 & 526.00 & 773.50 & 0.3139 \\
\hline Total assets (Teur) & 82.20 & 139.00 & 0.0663 & 152.00 & 160.50 & 0.3010 & 174.35 & 340.60 & 0.0422 & 219.20 & 392.50 & 0.0604 \\
\hline Growth of net sales (\%) & -9.80 & -14.90 & 0.0626 & -3.90 & -12.10 & 0.0886 & 3.10 & -4.55 & 0.2967 & 0.70 & 3.30 & 0.4564 \\
\hline Number of employees & 5.00 & 5.00 & 0.4527 & 5.00 & 6.00 & 0.2743 & 5.00 & 7.00 & 0.3717 & 6.50 & 9.00 & 0.1627 \\
\hline Net sales per employee (Teur) & 57.70 & 76.00 & 0.3752 & 100.75 & 76.00 & 0.2520 & 95.50 & 99.25 & 0.4743 & 100.85 & 89.90 & 0.2242 \\
\hline Gross profit (Teur) & 204.65 & 124.50 & 0.1453 & 213.00 & 245.50 & 0.1485 & 278.50 & 379.00 & 0.1654 & 241.50 & 441.60 & 0.1661 \\
\hline Growth of gross profit (\%) & -1.00 & -18.10 & 0.1092 & -14.05 & -8.70 & 0.5000 & 4.35 & 7.90 & 0.5000 & 0.30 & 5.80 & 0.3561 \\
\hline Gross profit per employee (Teur) & 33.90 & 37.65 & 0.4184 & 40.85 & 46.55 & 0.2734 & 51.85 & 61.60 & 0.1969 & 50.40 & 56.60 & 0.0589 \\
\hline EBITDA per net sales (\%) & -8.60 & -10.30 & 0.2712 & -9.20 & -12.50 & 0.2834 & 3.90 & 1.00 & 0.0294 & 2.90 & 0.65 & 0.1932 \\
\hline EBIT per net sales (\%) & -14.85 & -13.20 & 0.3260 & -11.85 & -14.00 & 0.0529 & 2.70 & -1.15 & 0.0087 & 0.00 & -3.25 & 0.0879 \\
\hline Traditional cash flow per net sales (\%) & -12.10 & -11.74 & 0.5000 & -12.79 & -13.72 & 0.1479 & 1.68 & -2.10 & 0.0409 & 1.07 & -2.33 & 0.0831 \\
\hline Quick ratio & 0.30 & 0.20 & 0.1453 & 0.50 & 0.30 & 0.0085 & 0.70 & 0.30 & 0.0482 & 0.80 & 0.55 & 0.1581 \\
\hline Current ratio & 0.45 & 0.40 & 0.1954 & 0.70 & 0.40 & 0.0206 & 1.00 & 0.90 & 0.0548 & 1.00 & 0.90 & 0.1101 \\
\hline Return on investment ratio (\%) & -25.45 & -38.90 & 0.2732 & -22.00 & -34.50 & 0.2843 & 7.20 & -8.20 & 0.0052 & 0.00 & -3.65 & 0.0898 \\
\hline Return on assets (\%) & -22.10 & -21.70 & 0.4696 & -16.10 & -24.20 & 0.1376 & 5.05 & -7.50 & 0.0052 & 0.00 & -3.00 & 0.0898 \\
\hline Equity ratio (\%) & -89.75 & -85.40 & 0.4696 & -84.50 & -82.40 & 0.3186 & 12.20 & -7.20 & 0.0000 & 9.00 & -8.05 & 0.0000 \\
\hline Net gearing & -1.60 & -1.30 & 0.0211 & -1.35 & -1.30 & 0.2773 & 1.20 & -4.30 & 0.0094 & 2.50 & -4.40 & 0.0002 \\
\hline Debt to net sales ratio (\%) & 65.40 & 73.25 & 0.2975 & 79.45 & 54.90 & 0.0584 & 30.90 & 42.00 & 0.0958 & 39.40 & 63.75 & 0.0550 \\
\hline Working capital (\%) & 1.65 & -0.05 & 0.1438 & -0.45 & -1.10 & 0.5000 & 8.25 & 5.20 & 0.2435 & 5.40 & 7.90 & 0.0550 \\
\hline Inventories per net sales (\%) & 7.40 & 5.15 & 0.3274 & 3.30 & 7.15 & 0.4111 & 11.40 & 10.20 & 0.3817 & 7.50 & 20.60 & 0.1241 \\
\hline Collection period of receivables (days) & 11.50 & 16.00 & 0.3175 & 21.00 & 18.00 & 0.2439 & 29.00 & 23.50 & 0.1682 & 21.00 & 36.00 & 0.1234 \\
\hline Payment period of payables (days) & 44.00 & 124.00 & 0.1394 & 81.50 & 115.50 & 0.1446 & 54.00 & 71.50 & 0.1609 & 56.00 & 84.00 & 0.0606 \\
\hline
\end{tabular}

Legend: $\S=1$-tailed Chi-Square median test.

\section{Appendix 2. The Auditor Variables of the Empirical Study}

1) Auditor gender $(0=$ female $\& 1=$ male $)$

2) Auditor quality grade (1 (failed) - 4 (no deficiencies in audit work))

3) Auditor tier $(0=$ HT (second tier) \& $1=$ KHT (first tier) $)$

4) Legal entity $(0=$ private auditor $\& 1=$ auditor in an audit firm)

5) Working type $(0=$ part-time $\& 1=$ full-time auditor $)$

6) Number of engagements annually

7) Number of hours on engagements

8) Number of hours per engagement

9) Auditor age (in years) 
10) Years after auditor exam (experience)

11) Taxable salary (annual, Euro)

12) Capital gain (annual, Euro)

13) Total salary (annual, Euro)

14) Number of hours on audit courses (last year, hours)

15) Compliance with standards: planning (0\% - 100\%)

16) Compliance with standards: analytical procedure $1(0 \%-100 \%)$

17) Compliance with standards: analytical procedure $2(0 \%-100 \%)$

18) Compliance with standards: conclusions (0\% - 100\%) 